\title{
Biomedical Engineer
}

National Cancer Institute

\section{Source}

National Cancer Institute. Biomedical Engineer. NCI Thesaurus. Code C51960.

An individual whose profession is to apply eng ineering principles to understand, modify, or control biologic systems, as well as design and manufacture products that can monitor physiologic functions and assist in the diagnosis and treatment of patients. 